\title{
Use of digital multispectral videography to assess seagrass distribution in San Quintín Bay, Baja California, Mexico
}

\section{Uso de videografía multiespectral digital para evaluar la distribución del pasto marino en Bahía San Quintín, Baja California, México}

\author{
David H. Ward ${ }^{1 *}$ \\ T. Lee Tibbitts ${ }^{1}$ \\ Alexandra Morton² \\ Eduardo Carrera-González ${ }^{3}$ \\ Richard Kempka ${ }^{2}$ \\ ${ }^{1}$ U. S. Geological Survey \\ Alaska Science Center \\ 1011 E, Tudor Rd. \\ Anchorage, Alaska 99503, USA \\ *E-mail: david_ward@usgs.gov \\ ${ }^{2}$ National Headquarters, Ducks Unlimited Inc. \\ One Waterfowl Way \\ Memphis, Tennessee 38120-2351, USA \\ ${ }^{3}$ Ducks Unlimited de Mexico \\ Ave. Vasconcelos 209 Ote. \\ Residencial San Agustín \\ Garza García CP 66260, Nuevo Leon, México
}

Recibido en septiembre de 2002; aceptado en mayo de 2003

\begin{abstract}
Apparent threats to the spatial distribution of seagrass in San Quintín Bay prompted us to make a detailed assessment of habitats in the bay. Six coastal habitats and three seagrass subclasses were delineated using airborne digital multispectral videography (DMSV). Eelgrass, Zostera marina, was the predominant seagrass and covered 40\% (1949 ha) of the areal extent of the bay in 1999. Eelgrass grew over a wide range of tidal depths from about $-3.0 \mathrm{~m}$ mean lower low water (MLLW) to about $1.0 \mathrm{~m}$ MLLW, but greatest spatial extent occurred in intertidal areas $-0.6 \mathrm{~m}$ to $1.0 \mathrm{~m} \mathrm{MLLW}$. Exposed-continuous (i.e., high density) eelgrass was the most abundant habitat in the bay. Widgeongrass, Ruppia maritima, was the only other seagrass present and covered 3\% (136 ha) of the areal extent of the entire bay. Widgeongrass grew in single species stands in the upper intertidal $(\geq 0.4 \mathrm{MLLW})$ and intermixed with eelgrass at lower tidal depths. Overall accuracy of the six habitat classes and three subclasses in the DMSV map was relatively high at $84 \%$. Our detailed map of San Quintín Bay can be used in future change detection analyses to monitor the health of seagrasses in the bay.
\end{abstract}

Key words: San Quintín Bay, airborne digital multispectral videography, seagrass distribution, Ruppia maritima, Zostera marina.

\section{Resumen}

Dada la existencia de aparentes amenazas para la distribución espacial del pasto marino, se llevó a cabo una evaluación detallada de los hábitats de Bahía San Quintín. Se delimitaron seis hábitats costeros y se identificaron tres subclases de pasto marino usando videografía multiespectral digital (DMSV) aérea. El pasto Zostera marina fue el predominante, cubriendo en 1999 el 40\% (1949 ha) de la extensión superficial de la bahía. Zostera marina crecía sobre un amplio rango de profundidades de marea desde $-3.0 \mathrm{~m}$ del nivel medio inferior de bajamar (MLLW) hasta cerca de $1.0 \mathrm{~m}$ del MLLW, pero su mayor extensión superficial ocurrió en la zona entre mareas de $-0.6 \mathrm{~m}$ a $1.0 \mathrm{~m}$ MLLW. De todos los hábitats de la bahía, los mantos continuos (i.e. de gran densidad) de Z. marina expuesta fueron los más abundantes. El único otro pasto marino presente fue Ruppia maritima, que cubría el 3\% (136 ha) de la extensión superficial total de la bahía. Este pasto se encontraba creciendo en mantos monoespecíficos en la intermareal superior $(\geq 0.4 \mathrm{MLLW})$, e intercalado con $Z$. marina a bajas profundidades de marea. La precisión global de las 6 clases de hábitat y de las 3 subclases en el mapa de DMSV fue relativamente alta en un $84 \%$. El mapa detallado obtenido para Bahía San Quintín puede ser utilizado para detectar cambios futuros y dar seguimiento al estado de salud de los pastos marinos en la bahía.

Palabras clave: Bahía San Quintín, videografía multiespectral digital, distribución de pastos marinos, Ruppia maritima, Zostera marina. 


\section{Introduction}

Embayments in Baja California are coming under increasing pressure from commercial and residential development (Ibarra-Obando and Escofet, 1987; Fermán-Almada et al., 2000; Aguirre-Muñoz et al., 2001). Anthropogenic changes to the coastal environment, especially those that affect water transparency, such as eutrophication and siltation, have been linked to reductions of seagrasses worldwide (Short and Wyllie-Echeverria, 1996; Hemmiga and Duarte, 2000). Losses have been reported for coastal areas of Europe (den Hartog and Polderman, 1975), southeast Asia (Fortes, 1988), Australia (Preen et al., 1995), and North America (Orth and Moore, 1983; Short and Burdick, 1996). Alterations to seagrass distribution and cover can, in turn, directly impact population status and distribution of associated marine organisms, including fish (Hobjoy et al., 1999; Matheson et al., 1999), waterbirds (Wilson and Atkinson, 1995), and marine mammals (Preen and Marsh, 1995).

The global scale of seagrass decline has highlighted the need to inventory and monitor these valuable natural resources. Local and regional assessments of seagrass spatial distribution and abundance can be used to focus conservation and management efforts. Spatial assessments can also enhance coastal research projects; for example, data can be used to evaluate the carrying capacity of seagrass beds for resident and migratory fauna, such as salmon (Simenstad and Cordell, 2000) and geese (Wilson and Atkinson, 1995), and serve as reference data for predictive spatial models (Camacho-Ibar et al., 2003). Programs that promote the use of standardized methods to assess cover and habitat changes in seagrass beds (e.g., Dobson et al., 1995; SeagrassNet, http://www.seagrassnet.org) have recently been established. Nevertheless, for many places in the world, including Mexico, no comprehensive monitoring effort exists that specifically targets seagrasses.

Although traditionally assessed through ground surveys, seagrass distribution is now commonly mapped using remote sensing techniques, such as aerial photography (Ferguson et al., 1993; Sheppard et al., 1995), airborne digital multispectral sensors (Mumby et al., 1997a, b), and satellite imagery (Ferguson and Korfmacher, 1997; Ward et al., 1997; Ward et al., 2003). Maps made from aerial photographs and digital multispectral data are considered better for monitoring spatial extent of seagrass meadows than maps from satellite images, because the former resolve data at higher spatial resolutions (1-3 m vs 10-30 m, respectively) allowing for more precise estimates (Dobson et al., 1995; Mumby et al., 1997a, b). High-resolution seagrass assessments can also be made with underwater sensors, such as side-scan hydroacoustics (McRoy and Bridges, 1998) and videography, but these sensors are usually cost-effective for small scale projects only (e.g., assessments around piers or docks) (Norris et al., 1997).

As part of a regional program to develop a data base of biological information on the coastal embayments of Baja California (Palacios, 2000), we assessed the distribution

\section{Introducción}

Las lagunas costeras de Baja California están sujetas a una creciente presión por el desarrollo comercial y residencial de la península (Ibarra-Obando y Escofet, 1987; Fermán-Almada et al., 2000; Aguirre-Muñoz et al., 2001). Las alteraciones antropogénicas del ambiente costero, especialmente las que afectan la transparencia del agua tales como la eutrofización y el azolve, han sido ligadas al abatimiento mundial de los bancos de pastos marinos (Short y Wyllie-Echeverria, 1996; Hemmiga y Duarte, 2000). Se ha reportado la disminución de éstos en áreas costeras de Europa (den Hartog y Polderman, 1975), el sureste asiático (Fortes, 1988), Australia (Preen et al., 1995) y Norteamérica (Orth y Moore, 1983; Short y Burdick, 1996). A su vez, las alteraciones de su distribución y cobertura impactan directamente el estado poblacional y la distribución de organismos marinos asociados a ellos, incluyendo peces (Hobjoy et al., 1999; Matheson et al., 1999), aves acuáticas (Wilson y Atkinson, 1995) y mamíferos marinos (Preen y Marsh, 1995).

La disminución de los pastos marinos a escala global ha resaltado la necesidad de llevar a cabo un inventario y dar seguimiento de estos valiosos recursos naturales. Las evaluaciones locales y regionales de la distribución espacial y abundancia de los pastos marinos puede utilizarse para dirigir los esfuerzos de manejo y conservación. Las evaluaciones espaciales también pueden potenciar los proyectos de investigación en la zona costera ya que, por ejemplo, los datos obtenidos pueden usarse para evaluar la capacidad de carga de los mantos de pasto marino para soportar poblaciones de fauna residente y migratoria (e.g., salmones [Simenstad y Cordell, 2000], gansos [Wilson y Atkinson, 1995]), y servir como referencia para modelos espaciales predictivos (Camacho-Ibar et al., en revisión). Recientemente se han establecido programas que promueven el uso de métodos estandarizados para evaluar los cambios de cobertura y de hábitat en los mantos de pasto marino (e.g., Dobson et al., 1995; SeagrassNet, http:// www.seagrassnet.org). Sin embargo en muchas partes del mundo, incluyendo a México, no se han realizado esfuerzos comprehensivos de seguimiento dirigidos específicamente a los pastos marinos.

Aunque la evaluación de la distribución del pasto marino se ha llevado a cabo tradicionalmente por medio de prospecciones terrestres, actualmente es común que ésta se realize mediante técnicas de sensores remotos tales como fotografía aérea (Ferguson et al., 1993; Sheppard et al., 1995), sensores aéreos multiespectrales digitales (Mumby et al., 1997a,b) e imágenes de satélite (Ferguson y Korfmacher, 1997; Ward et al., 1997; Ward et al., 2003). Los mapas hechos a partir de fotografías aéreas y datos multiespectrales digitales son considerados superiores a los mapas de imágenes de satélite para monitorear la extensión espacial de las praderas de pasto marino ya que los primeros manejan datos con una mayor resolución espacial (1-3 m vs. 10-30 m, respectivamente) permitiendo estimaciones más precisas (Dobson et al., 1995; Mumby et al., 1997a, b). También se pueden realizar evaluaciones de alta resolución 
of seagrasses in San Quintín Bay, an ecologically and economically important embayment (Massey and Palacios, 1994; Aguirre-Muñoz et al., 2001; Perez-Arteaga et al., 2002) situated on the Pacific coast of the Baja California Peninsula. Ward et al. (2003) conducted a change detection analysis of habitats in this bay between 1987 and 2000 using satellite imagery and found that seagrass extent had declined during this period, but this analysis was made at a relatively coarsescale (20-25 m resolution) and did not differentiate between seagrass species. Our approach in this current study was to develop a more detailed baseline map of seagrass extent for San Quintín Bay that can be used to monitor future changes in this valuable habitat at a finer scale. Accordingly, we used airborne digital multispectral videography (DMSV) to assess spatial distribution of seagrasses and other habitats in San Quintín Bay.

\section{Material and methods}

\section{Study area}

San Quintín Bay $\left(30^{\circ} 25^{\prime} \mathrm{N}, 116^{\circ} 00^{\prime} \mathrm{W}\right)$ is a $49-\mathrm{km}^{2}$, hypersaline embayment consisting of one permanent entrance and two sub-basins, locally know as Falsa Bay and San Quintín Bay and referred to in this paper as west bay and east bay, respectively (fig. 1). San Quintín Bay is characterized by extensive intertidal flats, shallow subtidal shoals, and narrow tidal channels. Tides are mixed semidiurnal with a maximum range of $2.0 \mathrm{~m}$ (Barnard, 1962). The climate is Mediterranean, with mean annual daily air and water temperatures ranging from $11^{\circ} \mathrm{C}$ to $22^{\circ} \mathrm{C}$ and $15^{\circ} \mathrm{C}$ to $22^{\circ} \mathrm{C}$, respectively (CabelloPasini et al., 2003). The bay receives little freshwater influence either from rainfall, averaging about $15 \mathrm{~cm} \mathrm{yr}^{-1}$, or from ground water drainage of the $2000-\mathrm{km}^{2}$-wide San Simón River watershed (Ibarra-Obando et al., 2001). Nutrient dynamics of this bay are driven primarily by a coastal upwelling system (Camacho-Ibar et al., 2003).

The seagrass meadows in San Quintín Bay are composed of unispecific and mixed stands of eelgrass, Zostera marina L., and widgeongrass, Ruppia maritima L. In general, eelgrass, the dominant seagrass in the bay, occurs in the low intertidal, whereas widgeongrass is found in the high intertidal. Macroalgae, primarily Ulva spp. and Enteromorpha spp., occur throughout the bay but are generally found intermixed in eelgrass meadows. Cordgrass (Spartina foliosa), salt-wort (Batis maritima), pickleweed (Salicornia spp.), and sea-blite (Sueda spp.) are the predominant salt marsh vegetation, and adjacent upland habitats are covered mostly by agricultural fields and coastal sage shrub vegetation (Wiggins, 1980; Aguirre-Muñoz et al., 2001). A few small-scale motels, trailer parks, and private residences are located along the northern shores of the east bay, and a small fishing village ( $<25$ residences) and three oyster processing facilities with several outbuildings are located along the shores of the west bay. de los pastos marinos por medio de sensores submarinos tales como sensores hidroacústicos laterales (McRoy y Bridges 1998) y videografía, pero estos sensores generalmente resultan más económicos para proyectos a escala pequeña (e.g., evaluaciones alrededor de muelles) (Norris et al., 1997).

Como parte de un programa regional para desarrollar una base de datos con información biológica acerca de las lagunas costeras de Baja California (Palacios, 2000), se evaluó la distribución de los pastos marinos en Bahía San Quintín, una importante laguna costera tanto desde el punto de vista económico como del ecológico (Massey y Palacios, 1994; Aguirre-Muñoz et al., 2001; Pérez-Arteaga et al., 2002) situada en la costa del Pacífico de la Península de Baja California. Ward et al. (2003) condujeron un análisis de detección de cambios en los hábitats de esta bahía ente 1987 y 2000 utilizando imágenes de satélite y encontraron que la extensión del pasto marino había disminuido durante tal periodo. Sin embargo, su análisis fue realizado a una escala relativamente burda (con una resolución de 20-25 m) y no permitía diferenciar entre una especie de pasto y otra. La presente aproximación se hizo con el fin de desarrollar un mapa de base más detallado de la extensión de los pastos marinos en Bahía San Quintín, que pueda ser utilizado para monitorear cambios futuros en este valioso hábitat a una escala más fina. En consecuencia, para evaluar la distribución espacial de los pastos marinos y de otros hábitats en Bahía San Quintín se utilizó videografía multiespectral digital aérea (DMSV, por sus siglas en inglés).

\section{Material y métodos}

\section{Área de estudio}

Bahía San Quintín $\left(30^{\circ} 27^{\prime} \mathrm{N}, 116^{\circ} 00^{\prime} \mathrm{W}\right)$ es una laguna costera hipersalina de $49 \mathrm{~km}^{2}$ de superficie que cuenta con una sola comunicación permanente con el océano y dos subcuencas conocidas localmente como Bahía Falsa y Bahía San Quintín, a las que en este trabajo nos hemos referido como bahía oeste y bahía este, respectivamente (fig. 1). Bahía San Quintín se caracteriza por tener extensas llanuras intermareales, bajos someros submareales y estrechos canales de marea. Las mareas son semidiurnas mixtas y tienen un rango máximo de $2.0 \mathrm{~m}$ (Barnard, 1962). Su clima es mediterráneo con temperaturas medias anuales diarias del aire y del agua que varían entre $11^{\circ}$ y $22^{\circ} \mathrm{C}$, y entre $15^{\circ}$ y $22^{\circ} \mathrm{C}$, respectivamente (Cabello-Pasini et al., 2003). La bahía recibe muy pocos aportes de agua dulce ya sea de precipitación pluvial (promedio $\sim 15 \mathrm{~cm} \mathrm{año}^{-1}$ ) o de escurrimientos de aguas freáticas del Río San Simón cuya vertiente abarca $2000 \mathrm{~km}^{2}$ (Ibarra-Obando et al., 2001). La dinámica de nutrientes en esta bahía está gobernada principalmente por un sistema de surgencias costeras (Camacho-Ibar et $a l$. , en revisión).

Las praderas de pasto marino en Bahía San Quintín están compuestas por mantos uniespecíficos y mixtos de Zostera marina L. y Ruppia maritima L. En general, el pasto 


\section{Data collection}

We acquired DMSV of San Quintín Bay on 15 January 1999 following standard photographic procedures for seagrass mapping (Dobson et al., 1995) and using a four-camera system (SpecTerra Systems, Ltd., Mark 1) mounted to the belly of a Partenavia twin-engine aircraft. Each video camera was fitted with a different wavelength color filter (i.e., 450, 550, 650, or $750 \mathrm{~nm}$ ) to optimize spectral delineation of seagrasses above and below the water surface. The aircraft maintained an altitude of $3000 \mathrm{~m}$ and flew 15 flight lines to cover the bay. The tide was low $(-0.2 \mathrm{~m}$ mean lower low water [MLLW]) and winds were light $(<10 \mathrm{~km} / \mathrm{h})$ during the image acquisition period $(1.6 \mathrm{~h})$. Although acquisition occured about three months after maximum aboveground biomass for eelgrass in this bay (Poumián-Tapia and Ibarra-Obando, 1999), this probably did not negatively bias assessments of seagrass cover and distribution because the data were obtained during an extreme low tide period with good water clarity for detecting seagrasses. Moreover, while shoot area decreases between October and January at San Quintín Bay, shoot density remains constant over this period (Cabello-Pasini et al., 2003), thus minimizing seasonal differences in seagrass cover.

Approximately 85 overlapping frames were joined together using corresponding tie-points in each four-banded raster image. The mosaic routine incorporated a simple model to adjust scene scale and position while maintaining overall spatial continuity. To minimize distortion in the final mosaicked image, the bay was partitioned into four quadrants and each quadrant was geo-referenced independently to a 1:22,000 scale base map (see below) using an array of differentially-corrected global positioning satellite (DGPS) ground control points positioned around the entire bay. The final mosaicked image was rectified to an UTM (Universal Transverse Mercator) projection and WGS-84 datum (1984 World Geodetic System) with a 2 -m pixel resolution. Spatial accuracy of the image was $<10 \mathrm{~m}$ and within mapping accuracy standards for submerged vegetation (Dobson et al., 1995).

No accurate reference map existed for San Quintín Bay to guide the mosaicking of the digital images; therefore, we created a base map of the bay from color aerial photographs. The photographs were taken from a twin-engine aircraft specially equipped for large format, vertical photography and obtained from $770 \mathrm{~m}$ altitude during a low tide (0.1 m MLLW) on 16 January 2000. The photographs were edge-matched together and geo-rectified using nearly 100 DGPS ground control points and a 1999 Indian Remote Satellite image (20-m resolution) as a backdrop. In addition to the base map, the color photographs also provided habitat information about a few small areas $(<25$ ha in total) in the DMSV coverage that had either been missed during the initial videography (e.g., salt marsh along the coast of the east bay) or were affected by geometric distortions caused by aircraft motion.

We classified the four-banded DMSV data using unsupervised image classifications techniques (Swain and Davis, dominante en la bahía, Z. marina, se presenta en la zona intermareal baja, mientras que $R$. maritima se encuentra en la intermareal alta. En toda la extensión de la bahía se presentan macroalgas, principalmente Ulva spp. y Enteromorpha spp., pero generalmente se encuentran intercaladas en las praderas de $Z$. marina. La vegetación predominante de los salitrales está compuesta de Spartina foliosa, Batis maritima, Salicornia spp. y Sueda spp., y los hábitats de las tierras adyacentes están cubiertos principalmente por campos agrícolas y vegetación de matorral costero (Wiggins, 1980; Aguirre-Muñoz et al., 2001). A lo largo de la margen norte de la bahía este, se encuentran algunos moteles pequeños, campos de casas rodantes y casashabitación, mientras que en las costas de la bahía oeste existe un pequeño campo pesquero $(<25$ casas $)$ y tres plantas de proceso de ostión con varios almacenes.

\section{Recolección de datos}

Se tomó una DMSV de Bahía San Quintín el 15 de enero de 1999 siguiendo los procedimientos fotográficos estándar para la elaboración de mapas de pasto marino (Dobson et al., 1995), usando un sistema de 4 cámaras (SpecTerra Systems, Ltd. Mark 1) montado en el fuselaje de un bimotor Partenavia. Para optimizar la delimitación espectral de los pastos marinos por encima y por debajo de la superficie del agua, cada cámara de video fue equipada con un filtro de color de diferente longitud de onda (i.e., 450, 550, 650 ó $750 \mathrm{~nm}$ ). El aeroplano mantuvo una altitud de $3000 \mathrm{~m}$ y, para cubrirla, sobrevoló la bahía en 15 líneas. Durante el periodo de toma de imagen $(1.6 \mathrm{~h})$ la marea se encontraba baja $(-0.2 \mathrm{~m}$ del nivel medio inferior de bajamar [MLLW]) y el viento soplaba ligeramente $(<10 \mathrm{~km} / \mathrm{h})$. Aunque la imagen se tomó 3 meses después de la máxima biomasa de Z. marina en tierra en esta bahía (Poumian-Tapia e Ibarra-Obando, 1999), este retraso probablemente no afectó negativamente las evaluaciones de cobertura y distribución del pasto marino, debido a que los datos se obtuvieron durante un periodo de mareas extremadamente bajas con buena claridad del agua para detectar el pasto marino. Además, mientras que el área de brotes en Bahía San Quintín disminuye entre octubre y enero, la densidad de éstos permanece constante a lo largo de este mismo periodo (Cabello-Pasini et al., 2003) minimizando así las diferencias estacionales en la cobertura de pasto marino.

Se unieron y traslaparon aproximadamente 85 cuadros, usando los puntos de unión correspondientes en cada imagen de cuadrícula de 4 bandas. La rutina para elaborar el mosaico de imágenes incorporó un modelo simple para ajustar la escala y posición de la vista, manteniendo la continuidad espacial global. Para minimizar la distorsión del mosaico final, la bahía se dividió en 4 cuadrantes y cada cuadrante se georeferenció de manera independiente a un mapa de base a escala 1:22,000 (ver abajo) usando un conjunto de puntos de control en tierra ubicados mediante un geoposicionador global por satélite corregido diferencialmente (DGPS) ubicados alrededor de toda la bahía. La imagen compuesta final se rectificó a una proyección UTM (Universal Transversa de Mercator), datum 


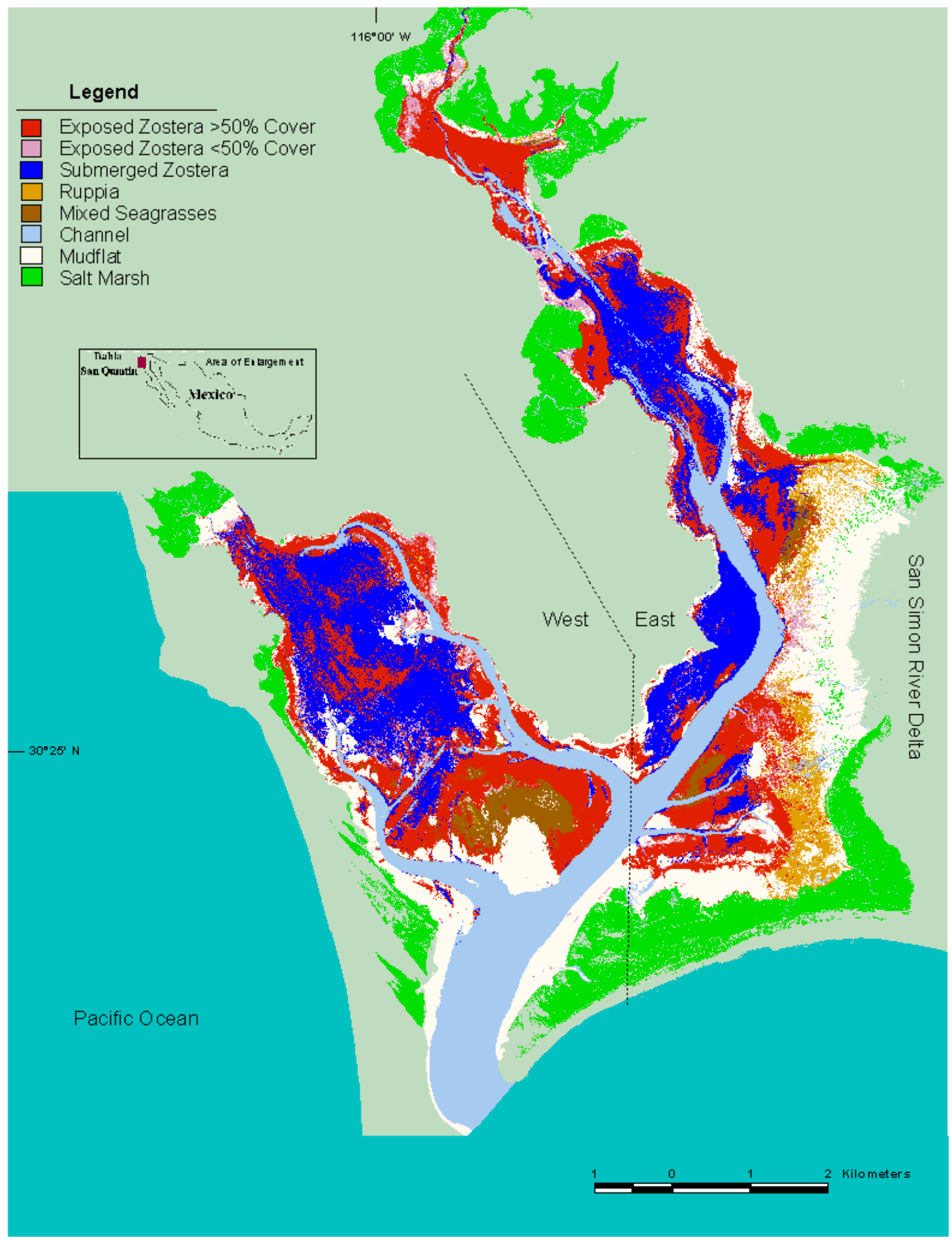

Figure 1. Distribution of seagrass and other habitats in San Quintín Bay, Baja California (Mexico), in 1999.

Figura 1. Distribución de los pastos marinos y otros hábitats de Bahía San Quintín, Baja California (México), en 1999. 
1978) and an isodata clustering algorithm to identify statistically separable spectral classes. We assigned each pixel to a spectral class using a maximum likelihood classifier. We subsequently evaluated all spectral classifications based on our knowledge of the area, review of the color photographs, and validation from ground samples. Grid cells were then assigned to one of six classes: channel (i.e., submerged unvegetated), eelgrass $(>90 \%$ of seagrass in each grid cell was eelgrass), widgeongrass $(>90 \%$ of seagrass in each grid cell was widgeongrass), mixed seagrasses (either species constituted $>10 \%$ of the seagrass present in each grid cell), mudflat (i.e., exposed unvegetated), or salt marsh. Eelgrass stands were further divided into three subclasses based on the spectral characteristics of the habitat relative to the height of the tide (covered or not covered by water) and shoot density (percent cover) following Ward et al. (2003). The three subclasses were: (1) exposed-continuous, defined as eelgrass with $\geq 50 \%$ cover that occurred at or above the water surface (i.e., $\geq-0.2 \mathrm{~m}$ MLLW); (2) exposed-patchy, defined as eelgrass with $<50 \%$ cover that occurred at or above the water surface; and (3) submerged, defined as eelgrass of any shoot density that occurred below the water surface (i.e., $<-0.2 \mathrm{~m}$ MLLW). The relative shallowness of submerged seagrass beds at San Quintín Bay allowed us to easily define the deep edge of all beds in the DMSV imagery.

We did not classify the dominant macroalgae, Ulva and Enteromorpha, because these macroalgae commonly occurred within eelgrass meadows where they could not be differentiated spatially or spectrally from eelgrass. In most cases, mats of Ulva and Enteromorpha formed on the substrate at the base of eelgrass shoots and were generally undetectable when viewed from above. It was also problematic to classify pure macroalgae mats because this spectral signature could not be verified with ground points (see below); macroalgae mats moved unknown distances via tidal currents, wind, and waves over the two- to six-month period between image acquisition and ground-truthing.

We verified class and subclass distinctions by visiting numerous field collection sites that were spread across the full spectrum of vegetational and physiographic conditions that existed in the bay. We made these ground truth assessments at 175 points in November and July 2000, and at 50 points in January 2002. At each point, we collected information on percent cover of each habitat class, average length and width of leaves of each seagrass species, and water depth.

We measured the accuracy of our habitat assessments using standard methods (Congalton, 1991). To gauge the accuracy of the enhanced DMSV classified map we used 275 independent points to calculate percent correct, errors of commission, and the Kappa statistic. Percent correct is simply the ratio of numbers of grid cells that were correctly classified by the total number of grid cells examined. Error of commission is a measure of the capability of the mapping technique to correctly identify areas where a habitat class is present; thus, an error of commission would occur when the DMSV classified image
WGS-84 (Sistema Geodésico Mundial de 1984) con una resolución de $2 \mathrm{~m}$ pixeles. La precisión espacial de la imagen fue $<10 \mathrm{~m}$ y estuvo dentro de los estándares de precisión del mapeo de vegetación sumergida (Dobson et al., 1995).

No existía ningún mapa de referencia de Bahía San Quintín para guiar la trama de las imágenes digitales, por ende creamos un mapa base de la bahía a partir de fotografías aéreas a color. Las fotografías fueron tomadas desde un bimotor especialmente equipado para tomar fotografías verticales de formato largo y se obtuvieron desde $770 \mathrm{~m}$ de altitud durante la marea baja (0.1 m MLLW) el 16 de enero de 2000. Se hicieron coincidir los bordes de las fotografías y éstas se georectificaron usando cerca de 100 puntos de control de DGPS y una imagen del Satélite Indian Remote (con resolución de 20 m) de 1999 como fondo. Además del mapa base, las fotografías a color proporcionaron también información acerca del hábitat en algunas áreas pequeñas $(<25$ ha en total $)$ dentro de la cobertura de la DMSV que, o bien se omitieron durante la videografía inicial (e.g., el salitral a lo largo de la costa de la bahía este), o que resultaron afectadas por distorsiones geométricas causadas por el movimiento del bimotor.

Los datos de la DMSV de 4 bandas fueron clasificados usando técnicas de clasificación de imágenes no supervisadas (Swain y Davis, 1978) y un algoritmo de agrupamiento de isodatos para identificar clases espectrales estadísticamente diferenciables. Cada píxel se asignó a una clase espectral usando un clasificador de máxima similitud y, subsecuentemente se evaluaron todas las clasificaciones espectrales con base en nuestro conocimiento del área, la revisión de las fotografías a color y la validación con muestras en tierra. Después se asignaron celdas de malla a 1 de 6 clases: canal (i.e., sumergido y sin vegetación), Z. marina ( $>90 \%$ del pasto marino en cada celda era $Z$. marina), $R$. maritima $(>90 \%$ del pasto en cada celda era $R$. maritima), pasto marino mezclado (alguna de las especies constituía $>10 \%$ del pasto marino presente en cada celda), salitral (i.e., expuesto sin vegetación), o marisma. Posteriormente se dividieron los mantos de pasto marino en 3 subclases con base en las características espectrales del hábitat con relación a la altura de la marea (cubierto o no cubierto por agua) y la densidad de los brotes (\% de cobertura) de acuerdo con Ward et al. (2003). Las 3 subclases fueron: (1) expuestocontinuo, definido como $Z$. marina con una cobertura $\geq 50 \%$ y presente al nivel o por encima de la superficie del agua (i.e., $\geq-0.2 \mathrm{~m}$ MLLW); (2) expuesto-discontinuo, definido como $Z$. marina con una cobertura $<50 \%$ y presente al nivel o por encima de la superficie del agua; y, (3) sumergido, definido como Z. marina con cualquier densidad de brotes por debajo de la superficie del agua (i.e., $<-0.2 \mathrm{~m}$ MLLW). Lo relativamente somero de los mantos sumergidos de pasto marino en Bahía San Quintín permitió definir fácilmente el borde profundo de todos los mantos por medio de las imágenes de DMSV.

Ulva y Enteromorpha no se clasificaron sobretodo porque estas macroalgas ocurrieron comúnmente entre praderas de $Z$. marina, donde no pudieron ser diferenciadas ni espacial ni 
predicted that a habitat class was present at a site but the class was not observed at the site. We calculated error of commission by dividing the number of correctly classified grid cells in a reference set by the predicted number of grid cells in that set. Values of $100 \%$ for each test represent perfect agreement between what the spectral data predict and what is present on the ground. The Kappa statistic is a measure of accuracy that incorporates the possibility of random chance agreements (Congalton, 1991); it ranges between -1 and 1 and a value of 1 means that there is $100 \%$ agreement between the classified map and the validation points. We determined the amount (hectares) of each habitat class using GIS software ARC/INFO.

\section{Results}

Seagrass, primarily eelgrass, was the most abundant habitat type in San Quintín Bay, comprising 46\% (2220 ha) of the areal extent of bay in 1999 (table 1; fig. 1). Eelgrass grew over a wide range of tidal depths from about $-3.0 \mathrm{~m}$ MLLW to about $1.0 \mathrm{~m}$ MLLW, but greatest extent occurred in intertidal areas at or above $-0.1 \mathrm{~m}$ MLLW. Stands of eelgrass with continuous cover $(>50 \%)$ dominated both the intertidal and subtidal areas of the bay and, overall, exposed-continuous eelgrass was the most abundant seagrass subclass in the bay.

Slightly more eelgrass $(55 \%)$ was located in the east bay, particularly in the northern portion and adjacent to the river delta (fig. 1). Widgeongrass covered 3\% (136 ha) of the areal extent of the entire bay and comprised about $6 \%$ of the total coverage of seagrasses (table 1; fig. 1). Small patches of low density widgeongrass were scattered throughout the bay, most commonly between 0.4 and $0.7 \mathrm{~m}$ MLLW. Below about $0.4 \mathrm{~m}$, widgeongrass grew sporadically and usually intermixed with eelgrass. Largest and densest stands of widgeongrass were situated in the east bay adjacent to the San Simón River delta (fig. 1). Most of the mixed seagrass beds (3\% of total area, $135 \mathrm{ha}$ ) grew in three distinct stands; the largest stand was located in the west bay directly north of the bay entrance and the two smaller stands were in the east bay adjacent to the channel near the San Simón River delta. Mixed stands were located primarily in the intertidal, between 0.3 and $0.0 \mathrm{~m}$ MLLW. The largest mixed stand was composed mainly of eelgrass, whereas the two smaller ones were dominated by widgeongrass.

Salt marshes $(20 \%, 980$ ha) and mudflats (19\%, 920 ha) were the next most abundant habitats in the bay (table 1). The largest salt marshes occurred along the extreme northern and southern margins of the bay, and the most expansive mudflats were associated with the river delta and entrance of the bay (fig. 1). Salt marshes dominated by pickleweed and cordgrass comprised about $66 \%$ (651 ha) and $9 \%$ (89 ha) of this habitat type, respectively. Channels covered $15 \%$ of the bay during the $-0.2 \mathrm{~m}$ low tide (table 1; fig. 1).

Overall, the accuracy of the DMSV classified map was high; $84 \%$ of the 275 control points were correctly classified and the Kappa statistic was $81 \%$, indicating that there was high espectralmente de la misma. En la mayoría de los casos, los tapetes de Ulva y Enteromorpha se formaban en el substrato de la base de los brotes de Z. marina y generalmente eran indetectables al verlos desde arriba. También fue problemático clasificar los tapetes de puras macroalgas ya que esta señal espectral no se podía verificar con puntos en tierra (ver abajo); los tapetes de macroalgas se movían distancias indeterminadas gracias a las corrientes de marea, al viento y a las olas en el periodo de 2 a 6 meses entre la toma de imágenes y la verificación desde tierra.

Se verificaron las diferencias entre clases y subclases visitando numerosos sitios de recolecta en el campo dispersos a lo largo de todo el espectro de condiciones vegetales y fisiográficas de la bahía. Estas verificaciones se realizaron en 175 puntos en noviembre y julio de 2000 , y en 50 puntos en enero de 2002. En cada punto se recolectó información sobre el porcentaje de cobertura de cada clase de hábitat, el promedio de longitud y anchura de las hojas de cada especie de pasto marino, y la profundidad.

Se midió la precisión de nuestra evaluación de hábitats usando métodos estándar (Congalton, 1991). Para medir la precisión del mapa de clasificación por DMSV mejorado se utilizaron 275 puntos independientes para calcular el porcentaje correcto, los errores de comisión y el estadístico Kappa. El porcentaje correcto es simplemente la proporción entre el número de celdas que fueron clasificadas correctamente y el número total de celdas examinadas. El error de comisión es una medida de la capacidad de la técnica de mapeo para identificar correctamente las áreas en las que un hábitat está presente, por lo que ocurre un error de comisión cuando la imagen clasificada por DMSV predice la presencia de una cierta clase de hábitat en un sitio cuando en la realidad ésta no ha sido observada en el mismo. Este error se calculó dividiendo el número de celdas de la malla correctamente clasificadas en un conjunto de referencia entre el número de celdas predichas en ese mismo conjunto. Valores del $100 \%$ para cada prueba representan una concordancia perfecta entre lo predicho por los datos espectrales y lo que realmente existe en el terreno. El estadístico Kappa es una medida de precisión que incorpora la posibilidad de cambios de concordancia al azar (Congalton, 1991); varía entre -1 y 1 , y un valor de 1 significa que existe una concordancia al $100 \%$ entre el mapa de clases y los puntos de verificación. Se determino la extensión (hectáreas) de cada clase de hábitat usando un programa de SIG Arc/Info.

\section{Resultados}

El tipo de hábitat más abundante en Bahía San Quintín fue el pasto marino, primordialmente Z. marina, y comprendió el 46\% (2220 ha) de la extensión superficial de la bahía en 1999 (tabla 1, fig. 1). Zostera marina estuvo presente creciendo en un amplio rango de profundidades de marea de alrededor de $-3.0 \mathrm{~m}$ MLLW a cerca de $1.0 \mathrm{~m}$ MLLW, sin embargo su mayor presencia ocurrió en zonas intermareales en o por encima de $-0.1 \mathrm{~m}$ MLLW. Los mantos de $Z$. marina de 
Table 1. Coverage estimates of seagrasses and other habitats in San Quintín Bay, Baja California (Mexico), using digital multispectral videography.

Tabla 1. Estimaciones de cobertura de pastos marinos y otros hábitats en Bahía San Quintín, Baja California (México), utilizando videografía multiespectral digital.

\begin{tabular}{lccc}
\hline & & \multicolumn{2}{c}{$\%$} \\
\cline { 3 - 4 } Habitat class & Hectares & Subtotal & Total \\
\hline Zostera marina $^{\mathrm{a}}$ & 1949 & & 40 \\
Exposed-continuous & 973 & 20 & \\
Exposed-patchy & 164 & 3 & \\
Submerged & 812 & 17 & 3 \\
Ruppia maritima & 136 & & 3 \\
Mixed seagrass & 135 & & 19 \\
Mudflat & 920 & & 15 \\
Channel & 754 & & 20 \\
Salt marsh & 980 & & 100 \\
Total & 4874 & & \\
\hline
\end{tabular}

a $Z$. marina includes exposed ( $\geq-0.2 \mathrm{~m}$ mean lower low water) and submerged $(<-0.2 \mathrm{~m}$ mean lower low water) beds, and continuous $(\geq 50 \%)$ and patchy $(<50 \%)$ cover.

b Either seagrass species constituted $>10 \%$ of the seagrass present.

map representation of the six habitat classes and the three subclasses of eelgrass. Errors of commission ranged from $50 \%$ to $91 \%$. Fewest errors of commission occurred when classifying the exposed-continuous eelgrass areas (91\%, 55 points), channels $(90 \%, 52$ points), submerged eelgrass $(89 \%, 83$ points), and mudflats ( $81 \%, 38$ points), while most errors occurred in pure widgeongrass areas $(69 \%, 14$ points), mixed seagrass areas $(50 \%, 12$ points), and exposed-patchy eelgrass areas $(71 \%, 21$ points). Habitat classification was particularly problematic when distinguishing between widgeongrass and mudflats ( $50 \%$ of the commission errors), exposed-patchy and exposed-continuous eelgrass (33\% of errors), and exposedpatchy eelgrass and mudflats (50\% of errors). When seagrass habitat types were collapsed into one seagrass class and no subclasses, the overall accuracy of the DMSV classified map increased to $89 \%$ and error of commission for seagrass areas to $91 \%$, indicating that DMSV was more accurate at a coarser scale of classification.

\section{Discussion}

DMSV was an effective technique for conducting a detailed assessment of seagrasses in San Quintín Bay. Using digital data, we were able to delineate six coastal habitats (including five seagrass classes and subclasses) at a fine scale (2-m resolution) with relatively high overall accuracy. This map provides the most finely discriminated estimates of intertidal and subtidal habitats for any embayment along the cobertura continua $(>50 \%)$ dominaron tanto la zona intermareal de la bahía como la submareal y, en general, la subclase de pasto marino más abundante en la bahía fue la $Z$. marina expuesta continua.

En la bahía este se encontró un poco más de $Z$. marina $(55 \%)$, particularmente en su parte norte adyacente al delta del río (fig. 1). Rupia maritima cubrió el 3\% (136 ha) de la extensión superficial de toda la bahía y comprendió alrededor del $6 \%$ de la cobertura total de pastos marinos (tabla 1 ; fig. 1 ). A lo largo de toda la bahía se encontraron pequeñas manchas dispersas de $R$. maritima, más frecuentemente entre 0.4 y $0.7 \mathrm{~m}$ MLLW. Rupia maritima se encontró creciendo de manera esporádica debajo de alrededor de $0.4 \mathrm{~m}$ e intercalada con $Z$. marina. Los bancos más grandes y más densos de $R$. maritima se encontraron en la bahía este adyacentes al delta del Río San Simón (fig. 1). La mayoría de los mantos mixtos de pastos marinos (35\% del área total, 135 ha) crecían en tres mantos distintos: el más grande en la bahía oeste directamente al norte de la entrada de la bahía y dos más pequeños en la bahía este, adyacentes al canal cercano al delta del Río San Simón. Los bancos mixtos se encontraron principalmente en la intermareal entre 0.3 y $0.0 \mathrm{~m}$ MLLW. El más grande estaba compuesto principalmente de de Z. marina, mientras que los dos más pequeños estaban dominados por $R$. maritima.

Salitrales $(20 \%$; 980 ha) y marismas (19\%; 920 ha) fueron los siguientes hábitats más abundantes en la bahía (tabla 1). Los salitrales más grandes se encontraron a los largo de las márgenes de los extremos norte y sur de la bahía y las marismas más extensas estuvieron asociadas al delta del río y la entrada de la bahía (fig. 1). Las áreas dominadas ( $>60 \%$ de la cobertura) por Salicornia spp. y Spartina foliosa comprendieron alrededor del 66\% (651 ha) y el 9\% (89 ha) del hábitat de salitrales. Los canales cubrieron el $15 \%$ de la bahía durante la marea baja de $-0.2 \mathrm{~m}$ (tabla 1 ; fig. 1 ).

En general, la precisión del mapa de clasificación por DMSV fue alta; $84 \%$ de los 275 puntos de control fueron clasificados correctamente, y el estadístico Kappa tuvo un valor de $81 \%$, lo que indica una buena representación en el mapa de las 6 clases de hábitat y las 3 subclases de Z. marina. Los errores de comisión variaron entre $50 \%$ y $91 \%$. El menor número de errores de comisión ocurrió al clasificar áreas expuestascontinuas de Z. marina (91\%, 55 puntos), canales (90\%, 52 puntos), Z. marina sumergida (89\%, 83 puntos), y marismas ( $81 \%, 38$ puntos) mientras que la mayor cantidad de éstos ocurrieron en áreas exclusivas de $R$. maritima (69\%, 14 puntos), áreas de pastos mixtos $(50 \%, 12$ puntos $)$, y áreas expuestasdiscontinuas de $Z$. marina (71\%, 21 puntos). La clasificación de hábitats fue particularmente problemática para distinguir entre $R$. maritima y las marismas $(50 \%$ de errores de comisión), entre Z. marina expuesta-discontinua y expuestacontinua (33\% de errores), y entre $Z$. marina expuestadiscontinua y las marismas (50\% de errores). Cuando los tipos de hábitat se juntaron en 1 sola clase de pasto marino, sin subclases, la precisión general del mapa de clasificación por 
Pacific coast of Mexico and improves upon previous habitat maps of San Quintín Bay made using ground survey data in 1960 (Dawson, 1962) and 1974 (Kramer, 1976), and satellite imagery in 1994 (Landsat-5 Thematic Mapper: Ducks Unlimited de Mexico, unpublished data), 1987, and 2000 (Satellite Pour l'Observation de la Terre [SPOT] and Landsat-7 Enhanced Thematic Mapper Plus [ETM+], respectively: Ward et al., 2003). These other efforts are less comprehensive as they discriminate fewer habitat types and are delineated at coarser scales, but they are useful for giving a historical perspective of seagrass distribution in the bay.

To make our estimates of seagrass extent directly comparable to estimates from other studies of San Quintín Bay and elsewhere in the region, we lumped widgeongrass into the eelgrass class and retained the three eelgrass subclasses. After these manipulations we found that the overall accuracy of the DMSV map was slightly higher $(87 \%$ vs $81 \%)$ than that of a similar map of San Quintín Bay (six coastal habitats, three seagrass classes) that was created from a 2000 satellite image of the Landsat-7 ETM+ (Ward et al., 2003). The high accuracy of the DMSV map can be attributed to the quality of this airborne imagery and our use of color aerial photography and extensive ground surveys to assist with habitat delineations. Interpretation of the aerial photography was especially useful for determining habitat types in small portions of the digital image (primarily in the west bay) that were afflicted with spectral radiometric problems (i.e., brightness differences between flightlines) caused by scattered high clouds during the original scanning.

Other studies have indicated that seagrass biomass (and indirectly areal extent) in San Quintín Bay did not differ between winter 1999 and winter 2000 (Cabello-Pasini et al., 2003; S. Ibarra-Obando and M. Poumián-Tapia, unpublished data). Yet, the estimate of seagrass areal extent was $6 \%$ higher in 1999 using the DMSV (2220 ha: this study) than in 2000 using Landsat-7 ETM+ (2068 ha: Ward et al., 2003). We attribute this slight difference to the greater spatial resolution of the DMSV map and the capacity of this technique to detect smaller patches of seagrass that would be missed in the satellite image. In contrast, the 1999 DMSV estimate was lower than the earliest remote imagery assessment of seagrass extent in San Quintín Bay made in 1987 (2390 ha) using SPOT imagery (Ward et al., 2003), suggesting that a loss of seagrass cover has occurred in San Quintín Bay over the last 13 years. A similar loss was detected by Ward et al. (2003) during a spatial change detection analysis comparing the SPOT and Landsat-7 ETM+ imagery.

Eelgrass, particularly high density intertidal meadows, is the predominant habitat in San Quintín Bay. These meadows represent some of the most extensive stands of intertidal eelgrass in the region (Ward et al., 2003). The abundance of intertidal eelgrass at San Quintín Bay is a unique feature of this bay relative to other embayments in Mexico, where eelgrass grows primarily subtidally (Meling-López and Ibarra-Obando, 1999; Cabello-Pasini et al., 2003). It is also one of the major
DMSV se incrementó al $89 \%$ y el error de comisión para las áreas de pasto marina lo hizo al 91\%, indicando que la DMSV era aún más precisa a una escala de clasificación más burda.

\section{Discusión}

La DMSV fue una técnica efectiva para llevar a cabo una evaluación detallada de los pastos marinos en Bahía San Quintín. Usando los datos digitales fue posible delimitar 8 hábitats costeros diferentes (incluyendo 5 clases de pastos marinos) a una escala fina (resolución de $2 \mathrm{~m}$ ) con una resolución general relativamente alta. Este mapa proporciona las estimaciones más detalladas de hábitats intermareales y submareales que existen para una laguna costera a lo largo de las costas mexicanas del Pacífico, y mejora los mapas previos de hábitats de Bahía San Quintín que fueron hechos usando datos de prospecciones terrestres de 1960 (Dawson, 1962) y 1974 (Kramer, 1976), e imágenes de satélite en 1994 (Landsat-5 Thematic Mapper: Ducks Unlimited de México, datos no publicados), 1987 y 2000 (Satellite pour 1'Observation de la Terre [SPOT] y Landsat-7 Enhanced Thematic Mapper Plus [ETM+], respectivamente) (Ward et al., 2003). Estos otros intentos son menos comprehensivos ya que discriminan menos tipos de hábitats y están delimitados a escalas más burdas, pero son útiles para contar con una perspectiva histórica de la distribución de los pastos marinos en la bahía.

Para hacer nuestras estimaciones directamente comparables con las de otros estudios hechos en Bahía San Quintín y en cualquier otro lugar de la región, se agrupó a $R$. maritima dentro de la clase de $Z$. marina y se mantuvieron 3 subclases de ésta. Después de este manejo se encontró que la precisión general del mapa por DMSV era ligeramente mayor $(87 \%$ vs. $81 \%$ ) que la de un mapa similar de Bahía San Quintín (6 hábitats coteros, 3 subclases de pastos marinos) que fue creado a partir de una imagen de satélite de 2000 del Landsat-7 ETM+ (Ward et al., 2003). La gran precisión del mapa de DMSV se puede atribuir a la calidad de sus imágenes aéreas y al uso que se hizo de fotografías áreas a color y de prospecciones terrestres para apoyar la delimitación de hábitats. La interpretación de la fotografía aérea fue especialmente útil para determinar los tipos de hábitats en partes pequeñas de la imagen digital (principalmente en la bahía oeste) que se vieron afectadas por problemas radiométricos espectrales (i.e., diferentes niveles de brillo entre los recorridos de vuelo) causadas por la presencia de nubes altas dispersas durante el barrido original.

Otros estudios han indicado que la biomasa de los pastos marinos (e indirectamente su extensión superficial) en Bahía San Quintín no difirió entre el invierno de 1999 y el de 2000 (Cabello-Pasini et al., 2003; Ibarra-Obando y Poumian-Tapia, datos no publicados). Aún así, la estimación de la extensión superficial fue un 6\% mayor en 1999 utilizando DMSV (2220 ha: este estudio) que en 2000 usando el Landsat-7 ETM+ (2068 ha: Ward et al., 2003). Esta pequeña diferencia se atribuye a la mayor resolución espacial del mapa de DMSV y a la capacidad de esta técnica para detectar pequeños mantos de 
factors contributing to the use of this bay by a variety of waterbirds (Massey and Palacios, 1994), including nearly the entire Pacific flyway population of black brant, Branta bernicla nigricans (Reed et al., 1998; Conant and Voelzer, 2002). The bay's significance for wintering and migrating black brant has prompted a recommendation for its designation as a wetland of international importance under the Ramsar Convention (Perez-Arteaga et al., 2002).

While the predominance of eelgrass in San Quintín Bay has been well known since the 1950s (Dawson, 1951, 1962), the presence and distribution of widgeongrass in the bay is less well documented. In 1992, Delgadillo et al. (1992) reported low densities of high intertidal widgeongrass in the bay, and we first noted dense patches $(>75 \%$ cover) of widgeongrass during the El Niño winter of 1997/1998. During this winter, widgeongrass grew in dense patches near the San Simón River delta and in sparse to moderately dense stands in the north end of the east bay and at the entrance to the west bay where none, or very low densities of this plant, had been observed in these areas in the previous 20 years (S. Ibarra-Obando and D. Ward, unpublished data). These same areas continued to support sparse to dense stands of widgeongrass in the winters of $1998 / 1999$ and $1999 / 2000$ based on interpretation of the DMSV (this study) and satellite (Ward et al., 2003) images. This apparent expansion of widgeongrass in San Quintín Bay may be in response to the rise in sea level (Cabanes et al., 2001) and sea-surface temperature (Zveryaev et al., 2000) that has occurred in this region, especially during the 1990s. Widgeongrass is an abundant intertidal seagrass in embayments south of San Quintín Bay along the Pacific coast of Baja California (S. Ibarra-Obando and D. Ward, unpublished data), where intertidal areas are more extensive and annual sea-surface temperatures are warmer than in this bay (Cabello-Pasini et al., 2003).

We found it difficult to reliably map the distribution of widgeongrass and mixed seagrass stands using the DMSV data alone (i.e., accuracy was about $30-40 \%$ without ground reference data). This is not unusual; researchers rarely use remote sensing techniques to distinguish between species of seagrass because of problems with spectral and spatial overlap (Mumby et al., 1997b). At San Quintín Bay, widgeongrass and mixed seagrass habitats comprised only a small portion $(<13 \%)$ of the seagrass in the bay and primarily occurred at the interface between eelgrass stands and mudflats. The spectral signal of the mixed species stands was not entirely distinct from the signals of either eelgrass or widgeongrass alone, and the spectral signal of single species stands of widgeongrass was often indiscernible from the signal of mudflat areas. The latter problem occurred because this plant grew in low densities (averaging $\sim 40 \%$ cover) and abundance $\left(<10 \mathrm{gDW} \mathrm{m}^{-2}\right)$ (D. Ward, unpublished data). We were able to circumvent these mapping problems by using the spectral data in combination with photo interpretation and ground surveys to attain reasonably good mapping accuracy for the widgeongrass $(69 \%)$ and mixed seagrass $(50 \%)$. The improved accuracy was pasto marino que podrían perderse en la imagen de satélite. En contraste, la estimación por DMSV de 1999 fue menor a la primera evaluación de la extensión de los pastos marinos en Bahía San Quintín por detección remota hecha en 1987 (2390 ha) usando imágenes del SPOT (Ward et al., 2003), lo que sugiere que Bahía San Quintín ha sufrido una pérdida en su cobertura de pastos marinos a lo largo de los últimos 13 años. Ward et al. (en revisión) encontraron una pérdida similar en un análisis de detección de cambios en el que compararon imágenes del SPOT y del Landsat-7 ETM+.

El hábitat predominante en Bahía San Quintín es $Z$. marina, particularmente en densas praderas en la zona intermareal. Estas praderas representan algunos de los mantos más extensos de Z. marina intermareal en la región (Ward et al., 2003). Esta abundancia de Z. marina intermareal en Bahía San Quintín es una característica única de esta bahía, en relación con otras lagunas costeras de México en las que $Z$. marina crece principalmente en la zona submareal (Meling-López e Ibarra-Obando, 1999; Cabello-Pasini et al., 2003). Este también es uno de los principales factores que contribuyen al uso de esta bahía por parte de una gran variedad de aves acuáticas (Massey y Palacios, 1994), incluyendo casi la totalidad de la población migratoria del Pacífico de la branta negra, Branta bernicla nigricans (Reed et al., 1998; Conant y Voelzer, 2002). La importancia de esta bahía para la migración e hibernación de la branta negra ha propiciado la recomendación para ser designada como humedal de importancia internacional por la Convención Ramsar (Pérez-Arteaga et al., 2002).

Aunque la predominancia de Z. marina en Bahía San Quintín ha sido bien conocida desde los años cincuenta (Dawson, 1951, 1962), la presencia y distribución de $R$. maritima se encuentra menos documentada en la bahía. En 1992 Delgadillo et al. (1992) reportaron densidades bajas de $R$. maritima en la zona intermareal alta de la bahía, y nosotros notamos por primera vez manchas densas ( $>75 \%$ de cobertura) de $R$. maritima por primera vez durante el invierno de El Niño de 1997-1998. Durante ese invierno $R$. maritima creció en mantos densos cerca del delta del Río San Simón, y en mantos de densidad baja a moderada en el extremo norte de la bahía este y a la entrada de la bahía oeste, áreas donde en los 20 años anteriores nunca se habían observado sino densidades muy bajas de esta planta (S. Ibarra-Obando y D. Ward, datos no publicados). De acuerdo a la interpretación de imágenes de DMSV (este estudio) y de satélite (Ward et al., 2003), durante los inviernos de 1998-1999 y 1999-2000 estas áreas continuaron soportando mantos de $R$. maritima de dispersos a densos. Esta aparente expansión de $R$. maritima en Bahía San Quintín puede ser en respuesta a la elevación del nivel del mar (Cabanes et al., 2001) y de su temperatura superficial (Zveryaev et al., 2000), la cual se ha presentado en esta región especialmente durante la década de los noventa. Rupia maritima es un pasto marino intermareal abundante en lagunas costeras de la costa Pacífico de Baja California al sur de Bahía San Quintín (S. Ibarra-Obando y D. Ward, datos no 
possible because beds of widgeongrass and mixed seagrass occurred in isolated (i.e., fixed) locations in the bay and could be differentiated with ground points. Species differentiation using remote sensing techniques combined with ground surveys may not be possible in other embayments where there are more than two species and spectral and spatial overlap is highly variable. Estimating widgeongrass areal coverage was important in our study because this species appears to be expanding its distribution in San Quintín Bay and a baseline map depicting widgeongrass extent will likely be useful in future seagrass assessments.

Future seagrass mapping efforts that require detailed assessments of seagrasses should consider using airborne digital imagery and/or color aerial photography. These techniques provide cost-effective high resolution products (Mumby et al., 1999). Table 2 outlines a comparison of the strength and weaknesses of airborne and space platforms for sensing seagrass distribution. Although satellite imagery can be obtained at lower cost than airborne imagery (Mumby et al., 1999), it is often difficult to obtain images from the desired area that were collected under environmental conditions appropriate for detecting seagrasses (e.g., no clouds, light winds, low tide) (Dobson et al., 1995). Other types of sensors are more expensive, but they allow more flexibility in timing of data collection. Currently, aerial photography and airborne digital sensors provide higher spatial resolution (Mumby et al., 1997a); however, future satellites will likely contain higher resolution sensors $(1-5 \mathrm{~m})$ that may improve their accuracy and reliability for mapping seagrass. Digital multispectral sensors are capable of collecting seagrass data over the widest electromagnetic spectrum range $(400-580 \mathrm{~nm})$ and therefore provide the greatest spectral resolution, while aerial photography has the narrowest range (one-analog band) (Mumby et al., 1997a). Satellite imagery requires the least amount of postprocessing time because data are already digital and mosaicking of images is rarely necessary. Digital sensors require less post-processing time than aerial photography, but the frames still need to be joined together for both of these techniques. With regard to accuracy, aerial photography and digital sensors have the advantage over satellite imagery, especially for detailed mapping. At coarse scale mapping, satellite imagery can be comparable with other imagery (Mumby et al., 1999).

Although we did not conduct a detailed cost analysis, we found that the costs of mapping seagrass in San Quintín Bay, including those associated with post-processing, were comparable between DMSV and color aerial photography. However, for the purpose of assessing all habitats, DMSV was superior to aerial photography because it could differentiate among seagrass species and cover types. Either technique should be used in conjunction with ground surveys that refine image classification and validate accuracy of the classified map. The frequency at which change detection analyses should be conducted is a critical issue and ultimately depends on the rate of change expected for an area. Given the current rate of publicados) en las que las superficies intermareales son más extensas y las temperaturas superficiales anuales son más elevadas (Cabello-Pasini et al., 2003).

Fue difícil ubicar en el mapa de manera confiable la distribución de $R$. maritima y de los mantos mixtos de pastos usando únicamente los datos de DMSV (i.e., sin las referencias en tierra se tuvo una precisión de 30-40\%), lo que no es inusual ya que rara vez los investigadores utilizan técnicas de sensores remotos para distinguir entre especies de pastos marinos debido a problemas de traslape espectral y espacial (Mumby et al., 1997b). En Bahía San Quintín, los hábitats de $R$. maritima y mantos mixtos de pasto marino constituyeron sólo una pequeña parte $(<13 \%)$ de los pastos marinos de la bahía y ocurrieron principalmente en la interfase entre mantos de Z. marina y marismas. La señal espectral de los mantos mixtos no era totalmente distinta de las señales de los mantos exclusivos de $Z$. marina o $R$. maritima, y la señal espectral de éstos últimos con frecuencia no se podía distinguir de la de las zonas de marismas. Este problema ocurrió porque $R$. maritima se encontraba creciendo en bajas densidades $(\sim 40 \%$ de cobertura, en promedio) y abundancias $\left(<10 \mathrm{gPS} \mathrm{m}^{-2}\right)$ (D. Ward, datos no publicados). Este problema se pudo burlar usando datos espectrales en combinación con fotointerpretación y prospecciones en tierra, para poder obtener una precisión razonablemente buena en la ubicación de $R$. maritima $(69 \%)$ y de los mantos mixtos (50\%) en el mapa. La mayor precisión fue posible gracias a que los mantos de $R$. maritima y pastos mixtos se presentaban en lugares aislados (i.e., fijos) de la bahía y pudieron ser diferenciados con la ayuda de puntos de referencia en tierra. Es posible que la diferenciación de especies usando técnicas de sensores remotos combinadas con prospecciones terrestres pueda no ser posible en otros cuerpos costeros en los que coexistan $>2$ especies y en los que el traslape espectral y espacial sea altamente variable. En nuestro estudio fue importante la estimación de la cobertura superficial de $R$. maritima ya que al parecer esta especie esta extendiendo su distribución en Bahía San Quintín y un mapa base que muestre la extensión de esta especie puede resultar muy útil en futuras evaluaciones de los pastos marinos en la zona.

La futura elaboración de mapas detallados en los que se evalúen los bancos de pastos marinos deberá contemplar el uso de imágenes digitales aéreas y/o fotografías aéreas a color. Estas técnicas rinden productos de alta resolución económicos (Mumby et al., 1999). La tabla 2 muestra una comparación de las fortalezas y debilidades de las plataformas aéreas y espaciales para detectar la distribución de los pastos marinos. Aunque las imágenes de satélite se pueden conseguir a menores costos que las aéreas (Mumby et al., 1999), con frecuencia es difícil conseguir imágenes del área deseada que hayan sido captadas en condiciones ambientales adecuadas para detectar los pastos marinos (e.g, despejado, con viento ligero y en marea baja) (Dobson et al., 1995). Otros tipos de sensores son más costosos, pero tienen la ventaja de ser más flexibles a la hora de tomar los datos. Actualmente, la fotografía aérea y los 
Table 2. General comparison of remote sensing platforms for seagrass mapping (after Mumby et al., 1997a, 1999).

Tabla 2. Comparación general de diferentes sensores remotos para el mapeo de pastos marinos (tomado de Mumby et al., 1997a, 1999).

\begin{tabular}{lccc}
\hline Specifications & Aerial photography & Airborne digital sensors $^{\mathrm{a}}$ & Satellite imagery $^{\mathrm{b}}$ \\
\hline Acquisition cost & Moderate-High & Moderate-High & Low-Moderate \\
Spatial resolution (m) & $1-2$ & $1-3$ & $10-30$ \\
Spectral bands & 1 & 4 to variable & $1-3$ \\
Post-processing time & High & Moderate & Low \\
Accuracy & High & High & Moderate \\
\hline a Includes Digital Multispectral Videography (DMSV) and Compact Airborne Spectrographic Imager (CASI). &
\end{tabular}

development (Fermán-Almada et al., 2000; Aguirre-Muñoz et al., 2001) and environmental change (Zveryaev et al., 2000; Cabanes et al., 2001) that is occurring in and around San Quintín Bay, as well as the recent (1987-2000) seagrass loss in the bay (Ward et al., 2003), we recommend a seagrass assessment within the next five years to determine if there is a negative trend in seagrass distribution and cover in San Quintín Bay.

\section{Acknowledgements}

This study was funded by the U.S. Fish and Wildlife Service through the North American Wetlands Conservation Act, Ducks Unlimited de Mexico, and the Alaska Science Center of U.S. Geological Survey. Jim Bredy and Al Cilurso of U.S. Fish and Wildlife Service-Region 2 collected the aerial photography. Ocean Imaging Corporation acquired and processed the digital multispectral videography. We are especially grateful to Matthew Anderson, Adrian Gall, Tyler Lewis, Danielle Mather, Ryan Mathis, Dina Roberts, and Marnie Shepherd for assistance collecting the reference data. We also thank Alejandro Cabello-Pasini, the staff of San Diego National Wildlife Refuge, Richard and Dorothy Wheeler, and James White for providing logistical support and assistance. Reviews by Sandy Wyllie-Echeverria and Isaí Pacheco-Ruíz improved the manuscript.

\section{References}

Aguirre-Muñoz, A., Buddemeier, R.W., Camacho-Ibar, V., Carriquiry, J.D., Ibarra-Obando, S.E., Massey, B.W., Smith, S.V. and Wuff, F. (2001). Sustainability of coastal resource use in San Quintin Bay, Mexico. Ambio, 30: 142-149.

Barnard, J.L. (1962). Benthic marine exploration of Bahía San Quintín, Baja California. Pacific Naturalist, 3: 251-274.

Cabanes, C., Cazenave, A. and Le Provost, C. (2001). Sea level rise during past 40 years determined from satellite and in situ observations. Science, 294: 840-842.

Cabello-Pasini, A., Muñiz-Salazar, R. and Ward, D.H. (2003). Annual variations of biomass and photosynthesis in Zostera marina $\mathrm{L}$. along the Pacific coast of Baja California, Mexico. Aquat. Bot., 1633: 1-17. sensores digitales aéreos proporcionan una mayor resolución espacial (Mumby et al., 1997a); sin embargo, es muy probable que en el futuro los satélites cuenten con sensores de mayor resolución (de 1 a $5 \mathrm{~m}$ ) que permitan mejorar la precisión y confiabilidad de los mapas de distribución de pastos marinos. Los sensores multiespectrales digitales pueden capturar datos de pastos marinos en el más amplio rango del espectro electromagnético (400-580 nm) y, por lo tanto, proporcionar la mayor resolución espectral, mientras que la fotografía aérea trabaja en el menor de los rangos (1 banda analógica) (Mumby et al., 1997a). Las imágenes de satélite demandan un mínimo de tiempo de post-proceso debido a que sus datos ya son digitales y rara vez requieren ser integradas en un mosaico. Los sensores digitales requieren menos tiempo de post-proceso que las fotografías aéreas, pero de cualquier manera en ambas técnicas los cuadros deben ser unidos y ajustados. Con respecto a la precisión, la fotografía aérea y los sensores digitales presentan ventajas sobre las imágenes de satélite, especialmente para la elaboración de mapas detallados. A una escala más burda, las imágenes de satélite pueden ser comparadas con otros tipos de imágenes (Mumby et al., 1999).

Aunque no se llevó a cabo un análisis de costos detallado, se encontró que el costo de realizar mapas del pasto marino de Bahía San Quintín por medio de DMSV o por fotografía aérea fueron comparables, incluyendo los costos asociados al postproceso. Sin embargo, para propósitos de evaluación de todos los hábitats, la DMSV fue superior a la fotografía aérea ya que pudo distinguir tanto especies de pasto marino como tipos de cobertura. Ambas técnicas deben ser utilizadas en conjunción con prospecciones terrestres que permitan afinar la clasificación de las imágenes y validar la precisión del mapa clasificado. Un punto crítico en esto es la frecuencia con la que se deben emprender los análisis de detección de cambios y ésta depende finalmente de la tasa de cambio esperada para una cierta área. Dadas las tasas actuales de desarrollo (FermánAlmada et al., 2000; Aguirre-Muñoz et al., 2001) y de cambio ambiental (Zveryaev et al., 2000; Cabanes et al., 2001) que se presentan en Bahía San Quintín y sus alrededores, así como la pérdida reciente (1987-2000) de pastos marinos en la bahía (Ward et al., 2003), se recomienda una nueva evaluación de los 
Camacho-Ibar, V.F., Carriquiry, J.D. and Smith, S.V. (2003). Nonconservative $\mathrm{P}$ and $\mathrm{N}$ fluxes and net ecosystem production in San Quintín Bay, Mexico. Estuaries, 26(5): 1220-1237.

Conant, B. and Voelzer, J.F. (2002). Winter waterfowl survey: Mexico west coast and Baja California. U.S. Fish and Wildlife Service Annual Report, Anchorage, AK.

Congalton, R.G. (1991). A review of assessing the accuracy of classifications of remotely sensed data. Remote Sensing of Environment, 37: 35-46.

Dawson, E.Y. (1951). A further study of upwelling and associated vegetation along Pacific Baja California, Mexico. J. Mar. Res., 10: 39-58.

Dawson, E.Y. (1962). Marine and marsh vegetation of Bahía San Quintín, Baja California. Pacific Naturalist, 3: 275-280.

Delgadillo, J., Peinado, M., de la Cruz, M., Martínez-Parras, J.M., Alcaraz, F. and de la Torre, A. (1992). Análisis fitosociológico de los saladares y manglares de Baja California, México. Acta Botánica Mexicana, 19:1:35.

Den Hartog, C. and Polderman, P.J.G. (1975). Changes in the seagrass populations of the Dutch Waddenzee. Aquat. Bot., 1: 141-147.

Dobson, J.E., Bright, E.A., Ferguson, R.L., Field, D.W., Wood, L.L., Haddad, K.D., Iredale, H., Jensen, J.R., Klemas, V.V., Orth, R.J. and Thomas, J.P. (1995). NOAA coastal change analysis program (C-CAP): Guidance for regional implementation. National Oceanic and Atmospheric Administration Tech. Rep. 123, U.S. Department of Commerce, Seattle, Washington.

Ferguson, R.L. and Korfmacher, K. (1997). Remote sensing and GIS analysis of seagrass meadows in North Carolina, USA. Aquat. Bot., 58: 241-258.

Ferguson, R.L., Wood, L.L. and Graham, D.B. (1993). Monitoring spatial change in seagrass habitat with aerial photography. Photogrammetric Engineering Remote Sensing, 59: 1033-1036.

Fermán-Almada, J.L., Arredondo-García, C. and García-Gastelum, A. (2000). Ecological program for the San Quintín Valley of Baja California. Technical Report for the State of Baja California, Institute of Marine Sciences, University of Baja California.

Fortes, M.D. (1988). Mangrove and seagrass beds of East Asia: habitats under stress. Ambio, 17: 207-213.

Hemminga, M.A. and Duarte, C.M. (2000). Seagrass Ecology. Cambridge Univ. Press.

Hobjoy, D.K., Officer, R.A. and Perry, G.B. (1999). Changes to demersal fish communities over two decades: 1970-1991. Mar. Freshwater Res., 50: 397-407.

Ibarra-Obando, S.E. and Escofet, A. (1987). Industrial development effects on the ecology of a Pacific Mexican estuary. Environ. Conserv., 14: 135-141.

Ibarra-Obando, S.E., Camacho-Ibar, V.F., Carriquiry, J.D. and Smith, S.V. (2001). Upwelling and lagoonal ecosystems of the dry Pacific coast of Baja California. In: U. Seeliger and B. Kjerfve (eds.), Coastal Marine Ecosystems of Latin America. Springer-Verlag, Germany, pp. 315-329.

Kramer, G.W. (1976). Winter ecology of black brant at San Quintin Bay, Baja California, Mexico. M.Sc. thesis, Humboldt State University, Arcata, California.

Massey, B.W. and Palacios, E. (1994). Avifauna of the wetlands of Baja California, Mexico: Current status. Stud. Avian Biol., 15: 45-57.

Matheson, R.E. Jr., Camp, B.K., Sorgard, S.M. and Bjorgo, K.A. (1999). Changes in seagrass assessments of fish and crustacean communities of Florida Bay mud banks: The effects of recent ecosystem change. Estuaries, 22: 534-551.

Meling-López, A.E. and Ibarra-Obando, S.E. (1999). Annual life cycles of two Zostera marina L. populations in the Gulf of California: Contrasts in seasonality and reproductive effort. Aquat. Bot., 65: 59-69. mismos dentro de los próximos 5 años para determinar si existe una tendencia negativa en su distribución y cobertura en Bahía San Quintín.

\section{Agradecimientos}

Este estudio fue financiado por U.S. Fish and Wildlife Service por medio de la North American Wetlands Conservation Act, por Ducks Unlimited de México, y por el Alaska Science Center de U. S. Geological Survey. Jim Bredy y Al Cilurso de la Región 2 de U.S. Fish and Wildlife Service recolectaron las fotografías aéreas. La videografía multiespectral digital fue tomada y procesada por Ocean Imaging Corporation. En especial, se agradece a Matthew Anderson, Adrian Gall, Tyler Lewis, Danielle Mather, Ryan Mathis, Dina Roberts y Marnie Shepherd por su ayuda para recolectar datos de referencia. También se agradece a Alejandro Cabello-Pasini, al personal del San Diego National Wildlife Refuge, Richard y Dorothy Wheeler, y a James White por su apoyo logístico y asistencia. Las revisiones de Sandy Wyllie-Echeverria e Isaí Pacheco-Ruíz ayudaron a mejorar el manuscrito.

Traducido al español por Manuel Gardea-Ojeda.

McRoy, C.P. and Bridges, K.W. (1998). Eelgrass survey of eastern Prince William Sound. U.S. Army Corps of Engineers. Unpublished Final Report, Anchorage, Alaska.

Mumby, P.J., Green, E.P., Edwards, A.J. and Clark, C.D. (1997a). Coral reef habitat-mapping: How much detail can remote sensing provide? Mar. Biol., 130: 193-202.

Mumby, P.J., Green, E.P., Edwards, A.J. and Clark, C.D. (1997b). Measurement of seagrass standing crop using satellite and digital airborne remote sensing. Mar. Ecol. Prog. Ser., 159: 51-60.

Mumby, P.J., Green, E.P., Edwards, A.J. and Clark, C.D. (1999). The cost-effectiveness of remote sensing for tropical coastal resources assessment and management. J. Environ. Manage., 55: 157-166.

Norris, J.P., Wyllie-Echeverria, S., Mumford, T., Bailey, A. and Turner, T. (1997). Estimating basal area coverage of subtidal seagrass beds using underwater videography. Aquat. Bot., 58: 269-287.

Orth, R.J. and Moore, K.A. (1983). Chesapeake Bay: An unprecedented decline in submerged aquatic vegetation. Science, 22: $51-52$.

Palacios, M.C.E. (2000). Inventory of coastal wetlands of Baja California. Technical report. Pro Esteros, 4492 Camino de la Plaza, Ensenada, Mexico.

Perez-Arteaga, A., Gaston, K.J. and Kershaw, M. (2002). Undesignated sites in Mexico qualifying as wetlands of international importance. Biol. Conserv., 107: 47-57.

Poumián-Tapia, M. and Ibarra-Obando, S.E. (1999). Demography and biomass of the seagrass Zostera marina in a Mexican coastal lagoon. Estuaries, 22: 879-889.

Preen, A.R. and Marsh, H. (1995). Response of dugongs to large-scale loss of seagrass from Hervey Bay, Queensland, Australia. Wildlife Res., 22: 507-519.

Preen, A.R., Lee Long, W.J. and Coles, R.G. (1995). Flood and cyclone related loss, and partial recovery of more than $1000 \mathrm{~km}^{2}$ of seagrass in Hervey Bay, Queensland, Australia. Aquat. Bot., 52: 3-17. 
Reed, A., Ward, D.H., Derksen, D.V. and Sedinger, J.S. (1998). Brant (Branta bernicla). In: A. Poole and F. Gill (eds.), The Birds of North America, No. 337. The Birds of North America, Philadelphia, PA.

Simenstad, C.A. and Cordell, J.R. (2000). Ecological assessment criteria for restoring anadromous salmonid habitat in Pacific Northwest estuaries. Ecol. Eng., 15: 283-302.

Sheppard, C.R.C., Matheson, K., Bythell, J.C., Murphy, P., BlairMyers, C. and Blake, B. (1995). Habitat mapping in the Caribbean for management and conservation: Use and assessment of aerial photography. Aquatic Conservation: Marine Freshwater Ecosystems, 5: 277-298.

Short, F.T. and Burdick, D.M. (1996). Quantifying eelgrass habitat loss in relation to housing development and nitrogen loading in Waquoit Bay, Massachusetts. Estuaries, 19: 730-739.

Short, F.T. and Wyllie-Echeverria, S. (1996). A review of natural and human-induced disturbance of seagrasses worldwide. Environ. Conserv., 23: 17-27.
Swain, P.H. and Davis, S.M. (1978). Remote Sensing: The Quantitative Approach. McGraw-Hill, New York.

Ward, D.H., Markon, C.J. and Douglas, D.C. (1997). Distribution and stability of eelgrass beds at Izembek Lagoon, Alaska. Aquat. Bot., 58: 229-240.

Ward, D.H., Morton, A., Tibbitts, T.L., Douglas, D.C. and CarreraGonzález, E. (in review). Long-term spatial change in eelgrass distribution at Bahía San Quintín, Baja California, Mexico, using satellite imagery. Estuaries, 26(6): in press.

Wiggins, I.L. (1980). Flora of Baja California. Stanford Univ. Press.

Wilson, U.W. and Atkinson, J.R. (1995). Black brant and springstaging use at two Washington coastal areas in relation to eelgrass abundance. Condor, 97: 91-98.

Zveryaev, I.I. and Selemenov, K.M. (2000). Decadel scale changes in the annual cycle of the north Pacific sea-surface temperature. Int. J. Climatol., 20: 1639-1651. 